\title{
$\mathrm{MFC}$ 의 금속 및 탄소전극에 의한 전기생산 특성과 오염저감 효과
}

\author{
권성현 ${ }^{1)}$ · 송형진 · 이은미 · 조대철 · 이인형 \\ 순천향대학교 에너지환경공학과, ${ }^{1)}$ 경상대학교 해양환경공학과(해양산업연구소) \\ (2010년 3월 3일 접수; 2010년 6월 3일 수정; 2010년 7월 16일 채택)
}

\section{Electricity Generation and De-contamination Effect for Characteristic Electrode Material in a Microbial Fuel Cell System Using Bay Sediment}

\author{
Sung Hyun Kwon"), Hyung Jin Song, Eun Mi Lee, Daechul Cho*, In Hyoung Rhee \\ Department of Energy \& Environmental Engineering, Soonchunhyang University, Asan 336-745, Korea \\ ${ }^{1)}$ Department of Marine Environmental Engineering/Institute of Marine Industry, Gyeongsang National University, \\ Tongyong 650-160, Korea \\ (Manuscript received 3 March, 2010; revised 3 June, 2010; accepted 16 July, 2010)
}

\begin{abstract}
Sediment works as a resource for electric cells. This paper was designed in order to verify how sediment cells work with anodic material such as metal and carbon fiber. As known quite well, sediment under sea, rivers or streams provides a furbished environment for generating electrons via some electron transfer mechanism within specific microbial population or corrosive oxidation on the metal surfaces in the presence of oxygen or water molecules. We experimented with one type of sediment cell using different anodic material so as to attain prolonged, maximum electric power. Iron, Zinc, aluminum, copper, zinc/copper, and graphite felt were tested for anodes. Also, combined type of anodes-metal embedded in the graphite fiber matrix-was experimented for better performances. The results show that the combined type of anodes exhibited sustainable electricity production for ca. $600 \mathrm{~h}$ with max. $0.57 \mathrm{~W} / \mathrm{m}^{2} \mathrm{Al} /$ Graphite. Meanwhile, graphite-only electrodes produced max. $0.11 \mathrm{~W} / \mathrm{m}^{2}$ along with quite stationary electric output, and for a zinc electrode, in which the electricity generated was not stable with time, therefore resulting in relatively sharp drop in that after $100 \mathrm{~h}$ or so, the maximum power density was $0.64 \mathrm{~W} / \mathrm{m}^{2}$. It was observed that the corrosive reaction rates in the metal electrodes might be varied, so that strength and stability in the electric performances(voltage and current density) could be affected by them. In addition to that, COD(chemical oxygen demand) of the sediment of the cell system was reduced by $17.5 \sim 36.7 \%$ in $600 \mathrm{~h}$, which implied that the organic matter in the sediment would be partially converted into non-COD substances, that is, would suggest a way for decontamination of the aged, anaerobic sediment as well. The $\mathrm{pH}$ reduction for all electrodes could be a sign of organic acid production due to complicated chemical changes in the sediment.
\end{abstract}

Key Words : Sediment cell, Anodic material, Metal, Graphite felt, Electricity, COD reduction

${ }^{*}$ Corresponding author : Daechul Cho, Department of Energy \& Environmental Engineering, Soonchunhyang University, Asan 336-745, Korea
Phone: +82-41-530-1341

Email: daechul@sch.ac.kr 


\section{1. 서 론}

화석 에너지 자원의 고갈, 지구 온난화와 환경오염 의 심화로 말미암아 에너지 이용 효율의 혁신적 향상 과 아울러 공해 문제도 해결할 수 있는 새로운 기술의 개발이 요구되고 있다. 이러한 세계적인 추세에 따라 신 에너지 기술로서 기대를 모으고 있는 연료전지분 야는 가장 주목 받는 대체에너지 기술 중의 하나로 대 체 에너지 수요에 가능성이 있는 일종의 전기화학 장 치이다(Choo 등, 2006).

한편, 수소, 메탄올 등의 인위적인 연료를 사용하는 기존의 연료전지와는 달리 자연의 다양한 유기성 자 원을 이용하는 미생물연료전지(microbial fuel cell, $\mathrm{MFC})$ 는 바이오 에너지의 한 분야로서 많은 관심과 함께 하수 슬러지, 산업 폐수 등 에너지 함량이 높은 유기성 폐수를 원료로 사용하는 연구로 이어졌다(Du 등, 2007). 즉 유기물 분해에 의한 $\mathrm{BOD}$ 또는 $\mathrm{COD}$ 의 감소와 함께(Liu 등, 2004; 노 등, 2006) 그 에너지의 일부가 전기적 에너지로 전환되는 것으로서 수년 전 만 하여도 미생물연료전지의 전력 발생량은 $0.1 \mathrm{~W} / \mathrm{m}^{2}$ 내외에 불과했으나, 전력을 증진시킬 수 있는 인자들 이 활발히 연구되면서 그 성능은 급속히 개선되고 있 다(Oh 등, 2004).

최근에 Lovley 등(1991)은 해저의 광범위한 유기 성 퇴적토를 연료로 활용한 퇴적토전지(sediment cell) 의 신·재생 에너지 측면에서의 잠재성을 제시하였 다. 퇴적토전지는 폐기되거나 매장자원으로부터 에너 지를 생산하는 동시에 환경정화적인 이차적 특성을 지녀 실용화 가능성이 거론되고 있다.

미생물 또는 퇴적토에 의해 생성된 전자의 전달 성 능을 향상시키기 위해서 전극재료의 연구 필요성은 지대하다. Schroder 등(2003)은 산화전극에 백금 촉매 를 사용하여 성능향상을 도모하였으나 비용적인 측면 에서 실용화가 어렵다. 금속전극 재료를 선택하면 필 연적으로 부식반응이 동반된다. 19세기 말에 철과 알 루미늄 등을 전극재료로 하는 음용수용 정수 시스템 과 여러 가지 폐수에 전기를 공급하여 전극반응을 통 해 폐수처리가 시도된 전기화학적 방법에 의한 수처 리 공법이 수행되었듯이(Logan과 Regan, 2006) 해양 퇴적토를 이용한 퇴적토 전지에서 금속전극의 사용은
용액 내의 부유물질 및 용해성 유 - 무기물과 반응하 여 불용성 침전물로 제거되거나 오염물이 흡착된 floc 과 전해반응 시 발생하는 $\mathrm{O}_{2}, \mathrm{H}_{2}$ 와 같은 가스와 접촉 하여 퇴적토 상부로 부상처리 되어 퇴적토의 정화작 용도 가능하게 한다.

이 논문에서는 기존의 미생물연료전지에서 많이 활용되는 graphite felt전극과 고속 산화반응을 일으키 는 금속전극을 결합한 복합전극을 이용하여 퇴적토전 지 시스템을 구성하였다. 전지시스템으로부터 실용적 수준의 전력이 생산될 수 있는지 검토하였으며 아울 러 퇴적토의 오염저감효과도 고찰하였다.

\section{2. 이론적 배경}

미생물연료전지는 일반적으로 산화전극부(anode chamber) 내부에 있는 전기활성세균이 연료로 주입된 유기물을 분해하여 전자와 수소이온을 생성함으로서 작동한다. 아래 식 (1)과 (2)에서 보여주는 바와 같이 세균들에 의해 유기물이 분해될 때 수소이온과 전자 가 생성되며, 이 수소이온은 양성자 교환막을 통하여 환원전극부(cathode chamber)로 이동한다. 또한 세균 들에 의해 생성된 전자는 전극을 통해 외부 서킷으로 이동하여 환원전극부로 이동한다. 이러한 전자의 흐 름이 전기에너지를 발생시킨다. 포도당을 연료로 이 용할 경우 산화전극(식 (1))과 환원전극(식 (2))에서의 반응은 다음과 같다(Robin 등, 1993).

$\mathrm{C}_{6} \mathrm{H}_{12} \mathrm{O}_{6}+6 \mathrm{H}_{2} \mathrm{O} \rightarrow 6 \mathrm{CO}_{2}+24 \mathrm{H}^{+}+24 e^{-}, \quad E^{0}=0.014 \mathrm{~V}$

$6 \mathrm{O}_{2}+24 \mathrm{H}^{+}+24 e^{-} \rightarrow 12 \mathrm{H}_{2} \mathrm{O}, \quad E^{0}=1.23 \mathrm{~V}$

일반적으로 미생물연료전지에 사용되는 전극 물질 로 graphite felt와 같은 탄소재질의 전극이 쓰이고 있 다. 탄소전극은 Table 1 에서와 같이 전도율이 비교적 낮으나 전극 표면적이 넓고 미생물과 친화적 특성 때 문에 전극 재료로 널리 쓰이고 있다. 
Table 1. Electrical conductivity of various electrode materials

\begin{tabular}{lc}
\hline Electrode Material & Electrical Conductivity $(\mathrm{S} / \mathrm{m})$ \\
\hline \hline Iron & $1.03 \times 10^{7}$ \\
Brass & $1.50 \times 10^{7}$ \\
Zinc & $1.67 \times 10^{7}$ \\
Copper & $5.80 \times 10^{7}$ \\
Graphite felt & 0.87 2.78 \\
Graphite & $7.00 \times 10^{4}$ \\
Aluminum & $3.66 \times 10^{7}$ \\
Silver & $6.14 \times 10^{7}$ \\
Carbon & $3.7 \times 10^{-1}$ \\
Platinum & $9.26 \times 10^{6}$ \\
Gold & $4.4 \times 10^{7}$ \\
Nickel & $1.39 \times 10^{7}$ \\
\hline
\end{tabular}

퇴적토전지에서는 산화전극부의 퇴적토가 전기 활 성을 띈 다양한 미생물뿐만 아니라 전자 주게로 작용 할 수 있는 다양한 화합물이 동시에 공존함으로써 (Tender 등, 2002) 산화작용이 발생하는 적절한 조건 에서라면 전기를 발생시킬 수 있다. 산화전극에 사용 되는 염분 퇴적토나 연안 퇴적토에서는 다음 식 (3) (5)의 산화 반응이 가능하다(Lovley, 2006).

$$
\begin{aligned}
& \mathrm{HS}^{-} \rightarrow \mathrm{S}_{(s)}+\mathrm{H}^{+}+2 e^{-} \\
& \mathrm{HS}^{-}+4 \mathrm{H}_{2} \mathrm{O} \rightarrow \mathrm{SO}_{4}^{2-}+9 \mathrm{H}^{+}+8 e^{-} \\
& \mathrm{CH}_{3} \mathrm{COOH}+2 \mathrm{H}_{2} \mathrm{O} \rightarrow 2 \mathrm{CO}_{2}+8 \mathrm{H}^{+}+8 e^{-}
\end{aligned}
$$

부식이란 금속표면의 원자가 그 결정격자에서 이 탈하여 환경성분과 화학적 또는 전기화학적으로 반응 하는 것을 말한다. 금속이 부식되기 위해서는 어떤 환 경적 불균일에 의해서 전위차가 형성되어야 하며, 이 전위차가 생기면 전자가 움직이게 되고 전지가 형성 되어 전류가 흐른다. 이 전류를 부식전류(corrosion current)라 하며 이 전류의 근원이 되는 전지를 부식전 지(corrosion cell)라 한다. 식 (6) (9)은 일반적인 부 식전지에서의 화학반응을 나타낸 것이다(Liu와 Logan, 2004).

$$
\text { Anode: } \quad M \rightarrow M^{n+}+\neq^{-}
$$

$$
\begin{aligned}
& \text { Cathode: } \quad 2 \mathrm{H}^{+}+2 e^{-} \rightarrow \mathrm{H}_{2} \\
& \mathrm{O}_{2}+4 \mathrm{H}^{+}+4 e^{-} \rightarrow 2 \mathrm{H}_{2} \mathrm{O} \\
& \mathrm{O}_{2}+2 \mathrm{H}_{2} \mathrm{O}+4 e^{-} \rightarrow 4(\mathrm{OH})^{-}
\end{aligned}
$$

식 (6)은 산화전극 반응으로서 전자를 생성시키는 반응이며, 식 (7) (9)은 환원전극 반응으로서 산화전 극 반응에 의해 생성된 전자를 소모하는 반응이다. 부 식전지는 미생물연료전지와는 달리 환원전극에서의 반응은 환경에 따라 다양한 반응이 일어난다. 대표적 인 환원 반응으로 식 (7), (8)은 $\mathrm{pH} 5$ 이하의 산성용액 에서 용존산소 용해 정도에 따른 수소가스와 물 생성 반응이며, 식 (9)은 $\mathrm{pH}$ 6이상의 용액에서의 환원 반응 이다. 이런 금속의 부식반응을 퇴적토전지에 적용할 경우, 산화전극부에 탄소전극 외 부식반응이 가능한 금속전극을 이용한다면 해양 퇴적토의 다양한 유기물 질 또는 수분과의 산화반응을 통해 부차적인 전자를 얻을 수 있다.

\section{3. 재료 및 방법}

\section{1. 퇴적물 시료 채취}

충남 아산시 인주면 부근 삽교호에서 퇴적토 시료 를 채취하였다. 삽교호 간석지의 수심에 따라 세 위치, $\mathrm{a}(0.5 \mathrm{~m}), \mathrm{b}(1 \mathrm{~m}), \mathrm{c}(2 \mathrm{~m})$ 를 선정하여 표면에서 시료를 채취하였다. 시료는 만조에서 간조로 바뀌는 시점에 수심이 깊은 지역에서 채취하였고 채취한 시료는 $4^{\circ} \mathrm{C}$ 에 보관하고 실험 전 상온에 충분히 노출시킨 후 사용 하였다.

\section{2. 전극 및 전지 구성}

퇴적토전지 실험에 사용된 시스템은 산화전극부와 환원전극부가 고상(퇴적토)과 액상(해수)으로 각각 자연 분리되는 1실형으로 그 구성은 다음과 같다(Fig. 1). 본 실험에 사용된 퇴적토전지의 반응기는 Pyrex 재질의 $500 \mathrm{~mL}$ 부피의 비커를 사용하였다. 산화전극 부의 총 부피는 $250 \mathrm{~mL}$ 이며, 먼저 $100 \mathrm{~mL}$ 의 수저 퇴 적물을 충진 한 뒤 토층 위에 제작한 전극을 설치하고 나머지 $150 \mathrm{~mL}$ 의 퇴적물을 적충 하였다. 환원전극부 는 수중을 폭기 시키지 않은 인공해수를 peristaltic pump 


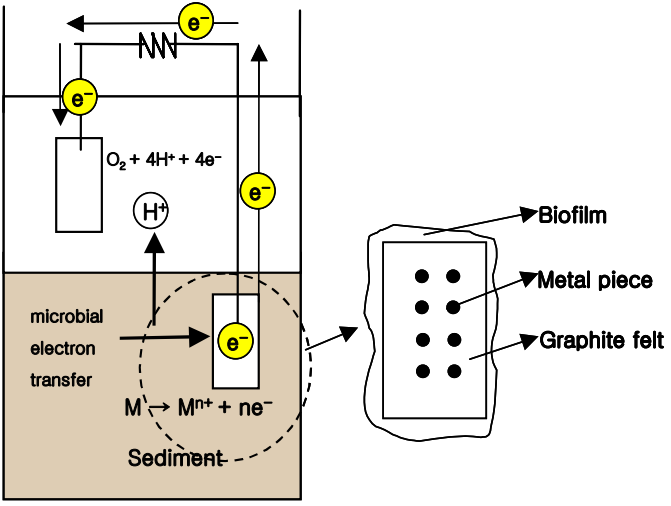

Fig. 1. Schematic diagram of sediment cells used in this experiments and Metal/Carbon electrodes. Sediment $250 \mathrm{~mL}$ was filled up in anode chamber.

(Model Perimax 12, SPETEC, Germany)를 이용하여 $200 \mathrm{~mL}$ 채워 넣고 1시간가량 퇴적토 부유물이 안정 화되기까지 정치한 후, 환원전극을 용액 중간부에 위 치시켰다.

산화전극은 단일재질전극으로 Redpoint(Korea)에 서 구입한 철, 황동, 알루미늄, 아연, 구리판의 금속전 극 $\left(5 \times 2 \times 0.5 \mathrm{~cm}^{3}\right)$ 과 탄소섬유조직으로 연결 된 다공성 구조의 graphite felt $\left(5 \times 2 \times 0.5 \mathrm{~cm}^{3}\right.$, GF series, Electrosynthesis, Amherst, NY, USA)를 탄소전극으로 사용 하였다. 또한 graphite felt의 다공성 표면에 금속을 잘 게 잘라 각 탄소전극 당 $0.2,0.4,0.6 \mathrm{~g}$ 씩 집적하여 복 합전극을 제작하였다. 환원전극으로는 carbon cloth $\left(5 \times 2 \mathrm{~cm}^{2}, \mathrm{SCCG}-5 \mathrm{~N}, \mathrm{Seal}, \mathrm{Italy}\right)$ 를 사용하였다. 각 전극의 전선은 직경 $3 \mathrm{P}$ 의 백금선과 전도성 에폭시 접 착제(Circuitworks, USA)를 사용하여 연결하였으며, $10 \Omega$ 의 외부저항을 연결하여 폐회로를 구성하였다.

\section{3. 퇴적토 성상분석}

삽교호에서 채취한 퇴적토의 유기물 함량(해저 퇴 적물 강열감량시험법)(배와 오, 2002), $\mathrm{pH}$ (Orion Star, Thermo, USA), COD (HS-COD-MR, Humas Co., Korea)를 분석하였다. 퇴적물 강열감량시험법에 따라 유기물 함량은 젖은 시료를 오븐에 $65^{\circ} \mathrm{C}$ 로 완전 히 건조시킨 후 곱게 분마하여 230메쉬 $(0.063 \mathrm{~mm})$ 체 를 통과시킨 후 시료 $5 \mathrm{~g}$ 을 도가니에 담고 오븐에 $550^{\circ}$
$\mathrm{C}$ 로 2 시간동안 가열, 냉각 후 전후무게로 계산하였다. 퇴적토의 평균 유기물 함량과 수분, 잔류 고형물의 비 율을 Table 2에 나타내었다.

Table 2. Ternary analysis of sediment

\begin{tabular}{cccc}
\hline & Water & $\begin{array}{c}\text { Organic } \\
\text { compound }\end{array}$ & $\begin{array}{c}\text { Fixed } \\
\text { solids }\end{array}$ \\
\hline \hline Content (\%) & $33.3 \pm 2.1$ & $14.6 \pm 1.3$ & $52.1 \pm 3.5$ \\
\hline
\end{tabular}

\section{4. 전기발생 분석}

생성되는 양극의 전압과 전류를 측정하기 위해 실 험이 진행되는 동안 외부 컴퓨터에 연결된 Digital Multi-Meter(model 34970A, Agilent Technologies, USA)를 이용하여 폐회로 상태에서의 전압(V)과 전류 (I)를 1 시간 단위로 분석하였다. 겸용 $\mathrm{pH} / \mathrm{ORP}$ meter(Orion Star, Thermo, U.S.A)를 이용하여 양 전 극의 $\mathrm{pH}$ 및 $\mathrm{ORP}$ 를 측정하였다. 전력 $(\mathrm{P})$ 및 전력 밀도 (p)는 다음의 식 (10), (11)을 사용하여 계산하였다. 여기서 $\mathrm{A}$ 는 산화전극의 표면적이다.

$$
\begin{aligned}
& P=I \times V \\
& \rho=\frac{P}{A}
\end{aligned}
$$

실측저항은 다음의 식 (12) 또는 (13)을 사용하여 계산하였다.

$$
\begin{aligned}
& R_{T}=R_{O X}+R_{E L}+R_{S E T} \\
& R_{T}=R_{B A C}+R_{E L}+R_{S E T}
\end{aligned}
$$

$\mathrm{R}_{\mathrm{T}}$ 는 퇴적토 전지에 관여된 모든 저항의 합이고, $\mathrm{R}_{\mathrm{Ox}}$ 는 금속 표면에 부식반응으로 인한 산화 막의 저 항 값, $\mathrm{R}_{\mathrm{EL}}$ 은 전극 자체 저항, $\mathrm{R}_{\mathrm{SET}}$ 는 고정저항이다. 한편, graphite felt를 양극에 사용한 경우는 $R_{\mathrm{OX}}$ 대신 $\mathrm{R}_{\mathrm{BAC}}$ 을 사용하여 퇴적토 내 존재하는 미생물(특히 매 개체 없는 전자전달체계를 가진)에 의한 가상적 전기 저항을 나타내었다.

한편, 탄소 및 복합전극의 단면은 SEM(Model 
CX-100S, COXEM, Korea)을 사용하여 관찰하였다.

\section{4. 결과 및 고찰}

\section{1. 퇴적토에 따른 전기발생 및 퇴적토변화}

수심에 따른 퇴적토의 화학적 특성을 Table 2에 나 타내었다. 그 중 c지역이 초기 COD $2416 \mathrm{mg} / \mathrm{L}$ 로 가 장 높았고(Table 2), $\mathrm{pH}$ 범위는 7.7 7.9로 약알칼리 성이었으며 ORP는 약 $70 \mathrm{mV}$ 였다.
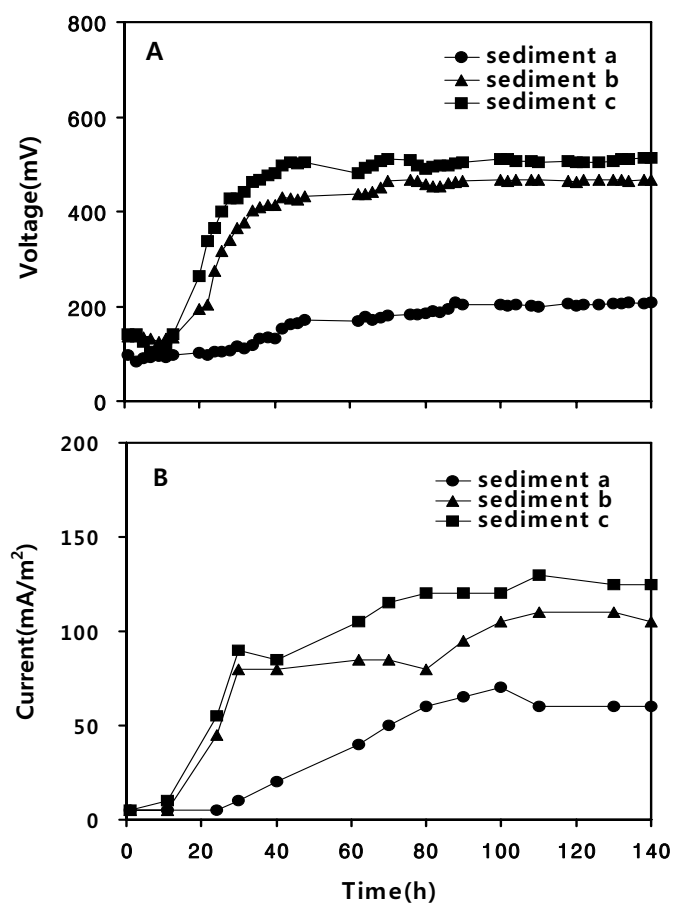

Fig. 2. Voltage (A) and current density (B) from sediment cells with different sediment $(10 \Omega)$.

산화전극으로 graphite felt전극을 사용한 실험 결 과 수심이 깊은 지역의 퇴적토일수록 전압과 전류가 높은 경향을 보였으며(Fig. 2), 퇴적토 초기 COD와 전 압, 전류밀도가 상관성이 높다고 판단된다(Table 3). 이후 퇴적토전지의 실험에 사용된 시료는 가장 수심 이 깊은 지역의 퇴적토 c로 통일하였다.
Table 3. Voltage and current changes with COD $(10 \Omega$ of an external resistor)

\begin{tabular}{cccc}
\hline Sediment & $\begin{array}{c}\mathrm{COD}_{0} \\
(\mathrm{mg} / \mathrm{L})\end{array}$ & $\begin{array}{c}\text { Voltage } \\
(\mathrm{mV})\end{array}$ & $\begin{array}{c}\text { Current density } \\
\left(\mathrm{mA} / \mathrm{m}^{2}\right)\end{array}$ \\
\hline \hline $\mathrm{a}$ & 2361 & 208 & 60 \\
$\mathrm{~b}$ & 2407 & 467 & 105 \\
$\mathrm{c}$ & 2416 & 514 & 125 \\
\hline
\end{tabular}

\section{2. 금속전극의 전기발생 및 퇴적토 변화}

산화전극부에 금속전극을 설치했을 때 72 시간동안 각 전극의 전기발생결과를 Fig. 3에 나타내었다. 비교 대상으로 동일한 단면적의 graphite felt전극을 동시에 운전하였다.

모든 금속 전극은 운전 시작 시 약 $700 \mathrm{mV}$ 의 높은 전압과 $1 \mathrm{~mA}$ 이상의 전류를 발생시키지만 72 시간 동 안 전압, 전류 값이 급속히 소진됨을 알 수 있다. 즉, 퇴적토전지에서 금속전극 중 최대전력밀도는 $\mathrm{Al}$ 전극 으로 $488 \mathrm{~mW} / \mathrm{m}^{2}$ 로 나타나(Table 4) graphite felt전극 보다는 약 11 배 높은 값이었지만, 비교적 안정된 전기 발생을 보인 탄소전극과는 달리 시간이 경과할수록 전기발생 효율이 감소하는 경향을 보였다.

Table 4. Production of maximum power density and current density from various metal electrodes $(10 \Omega)$

\begin{tabular}{ccc}
\hline Electrode & $\begin{array}{c}\text { Maximum power } \\
\text { density }\left(\mathrm{mW} / \mathrm{m}^{2}\right)\end{array}$ & $\begin{array}{c}\text { Maximum } \\
\text { current density } \\
\left(\mathrm{mA} / \mathrm{m}^{2}\right)\end{array}$ \\
\hline \hline $\mathrm{Al}$ & 488 & 655 \\
$\mathrm{Zn}$ & 424 & 635 \\
$\mathrm{Fe}$ & 436 & 605 \\
$\mathrm{Cu}$ & 387 & 610 \\
$\mathrm{Zn} / \mathrm{Cu}$ & 298 & 440 \\
Graphite felt & 44 & 90 \\
\hline
\end{tabular}

금속전극의 경우 장시간 퇴적토와의 복잡한 부식 반응으로 인해 안정한 전기 발생이 어려운 것으로 보 인다. 그 이유는 금속의 부식속도에 영향을 미치는 수 저 퇴적물의 $\mathrm{pH}$ 와 용존산소의 영향으로 전극 주위에 산화막으로 인한 전극저항이 형성되기 때문이다(강, 2008). 

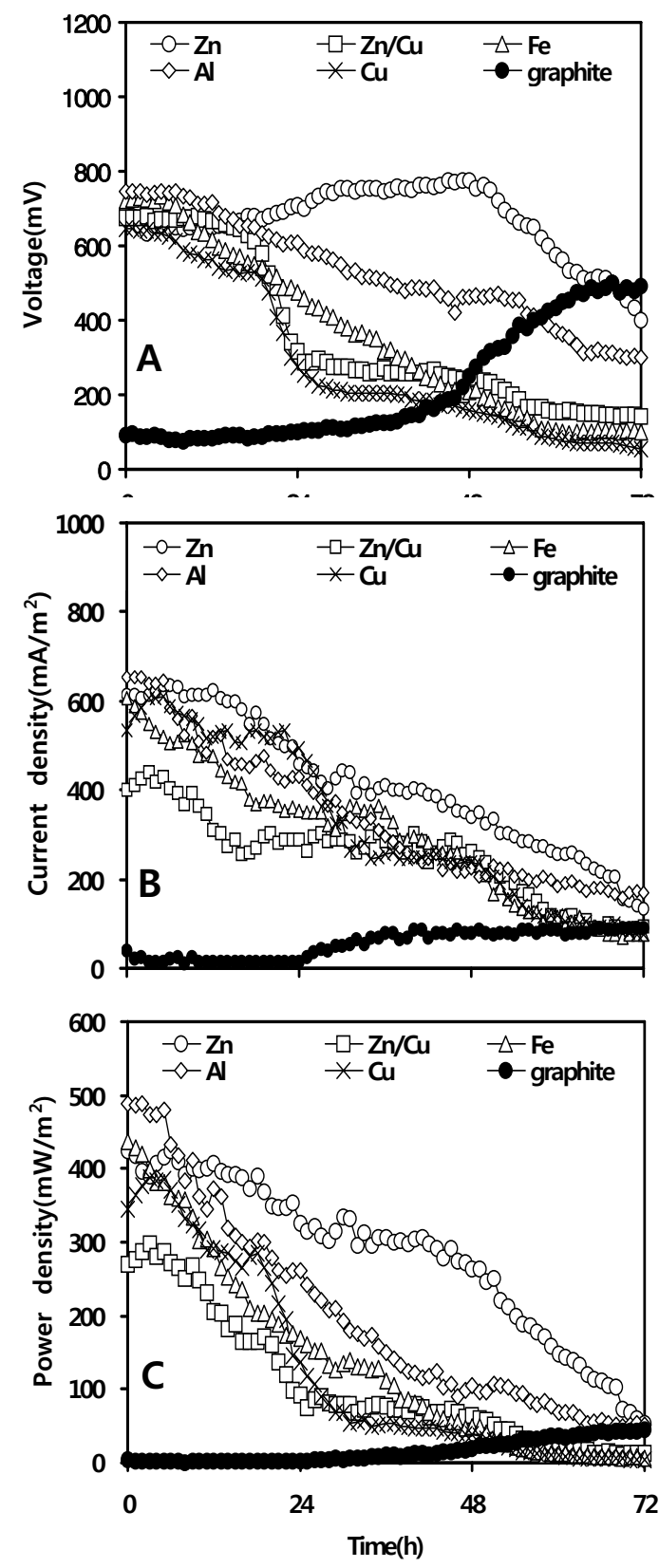

Fig. 3. Effect of various metal electrodes on the performance of the sediment cells (10 $\Omega)$ : Voltage (A); Current density (B); Power density (C).
Table 5. Standard reduction potential for metal

\begin{tabular}{cc}
\hline Reaction & Standard potential, $\mathrm{E}^{0}(\mathrm{~V})$ \\
\hline \hline $\mathrm{Al}^{3+}+2 \mathrm{e}^{-}=\mathrm{Al}$ & -1.662 \\
$\mathrm{Zn}^{2+}+2 \mathrm{e}^{-}=\mathrm{Zn}$ & -0.762 \\
$\mathrm{Fe}^{2+}+2 \mathrm{e}^{-}=\mathrm{Fe}$ & -0.447 \\
$\mathrm{Cu}^{2+}+2 \mathrm{e}^{-}=\mathrm{Cu}$ & +0.342 \\
\hline
\end{tabular}

이론적인 금속의 산화력은 $\mathrm{Al}>\mathrm{Zn}>\mathrm{Fe}>\mathrm{Cu}$ 순으 로 Fig. 3의 전압, 전류발생 크기와 일치하는 모습을 보였다. 즉, 금속전극에 의한 전기발생 특성이 금속의 이온화 경향 및 표준 환원 전위와 밀접한 관계를 가짐 을 알 수 있다(Table 5 참조)(Jones, 1996).

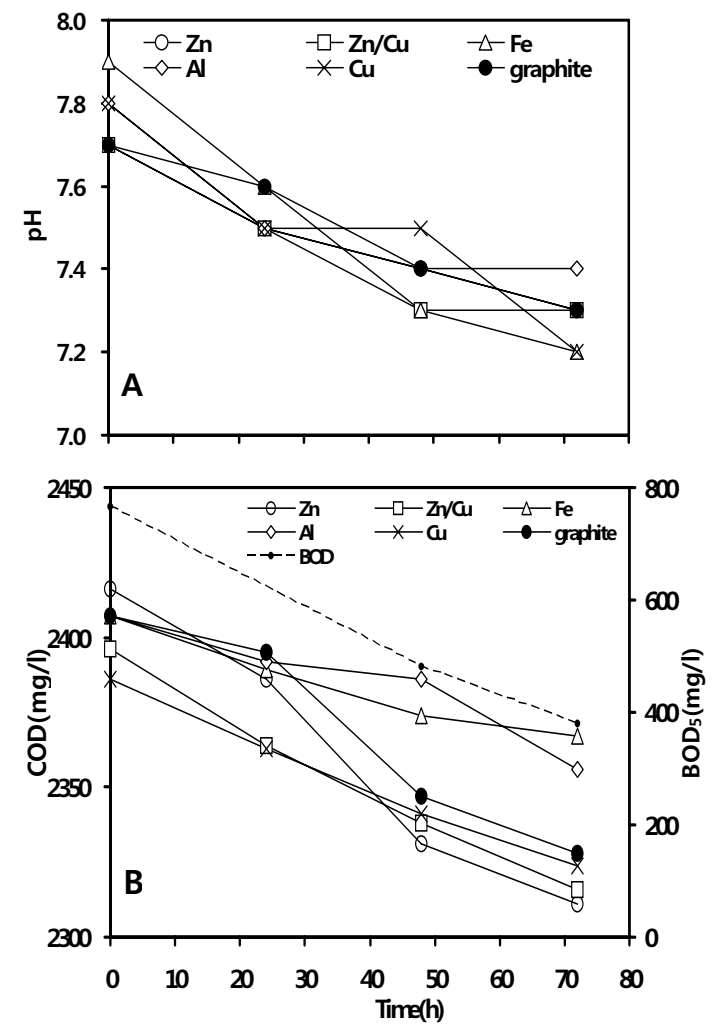

Fig. 4. $\mathrm{pH}(\mathrm{A})$ and $\mathrm{COD}\left(\right.$ or $\left.\mathrm{BOD}_{5}\right)(\mathrm{B})$ changes over time in sediment cells using various metal electrodes. 
Fig. 4는 전기발생에 따른 퇴적토의 변화를 나타낸 것이다. 전지가 운전되는 동안 퇴적토의 $\mathrm{pH}$ 값은 평균 7.8 에서 7.3 수준으로 감소하였으며 $\mathrm{COD}$ 변화량은 $\mathrm{Zn}$ 전극의 경우 $4.3 \%$ 의 제거율을 보였으며 $\mathrm{Fe}$ 전극이 가장 낮은 $1.7 \%$ 정도였다. $\mathrm{Zn}$ 전극에서 $\mathrm{BOD}$ 는 767 $\mathrm{mg} / \mathrm{L}$ 에서 3 일후 $381 \mathrm{mg} / \mathrm{L}$ 로 크게 감소하여 $60 \%$ 의 제거율을 보인 바, 퇴적토 중 유기물 비율이 $15 \sim 16 \%$ 정도로 작기 때문에 $\mathrm{COD}$ 에 비해 상대적으로 제거율 이 컸다. $\mathrm{COD}$ 나 $\mathrm{BOD}$ 가 감소하며 $\mathrm{pH}$ 가 떨어지는 전 형적인 모습은 전기발생에 따른 net산화반응이 촉발 한 미생물 또는 유-무기물 간의 복합적 화학작용이 라 추론되며 향후 분석적인 연구가 더 필요할 것이 다.

\section{3. 복합전극의 전기발생}

Al-graphite felt, Zn-graphite felt, Cu-graphite felt 3종류의 복합전극을 사용한 퇴적토전지의 전기발생 을 graphite felt전극과 비교하여 Fig. 5에 나타내었다. 복합전극은 알루미늄과 아연, 구리금속조각을 graphite felt 내 매트릭스에 Fig. 1처럼 집적한 전극으로서 금 속전극에 비해 초기에는 전압 및 전류가 낮게 측정되 었지만 장시간 $(600 \mathrm{~h})$ 에 걸쳐 비교적 높은 전압과 전 류가 유지되고 있음을 알 수 있다. Al- graphite felt전 극의 경우 $420 \mathrm{mV}$ 와 $316 \mathrm{~mA} / \mathrm{m}^{2}$ 로 출발하였고, $\mathrm{Zn}$ graphite felt전극의 경우는 초기 $343 \mathrm{mV}$ 및 156 $\mathrm{mA} / \mathrm{m}^{2}$ 를 보였다. 예상대로 $\mathrm{Cu}$-graphite felt전극이 복 합전극 중 가장 낮은 효율을 보였다.

복합전극에서의 전기발생 특이점은 순수 금속전극 과 달리 전압과 전류의 전개가 비교적 완만하게 증가 하며 처음 3 4일간의 등락기를 지나면 상당히 안정 적인 패턴을 보인다는 것이다. 가능한 이유로는 graphite felt 매트릭스에 갇힌 금속파편이 수분 또는 산화제와 충분히 접촉하기까지 일종의 확산 또는 반 응지체를 나타내기 때문으로 보인다.

Al-graphite felt전극의 최대 전압, 최대 전류밀도는 각각 $1066 \mathrm{mV}, 624 \mathrm{~mA} / \mathrm{m}^{2}$ 였으며, 최대 $571 \mathrm{~mW} / \mathrm{m}^{2}$ 의 전력밀도를 보였다. Zn-graphite felt전극의 경우 $900 \mathrm{mV}, 426 \mathrm{~mA} / \mathrm{m}^{2}$ 의 최대 전압, 전류밀도를 기록 하였으며 $358 \mathrm{~mW} / \mathrm{m}^{2}$ 의 전력밀도를 보였다(Table 6).
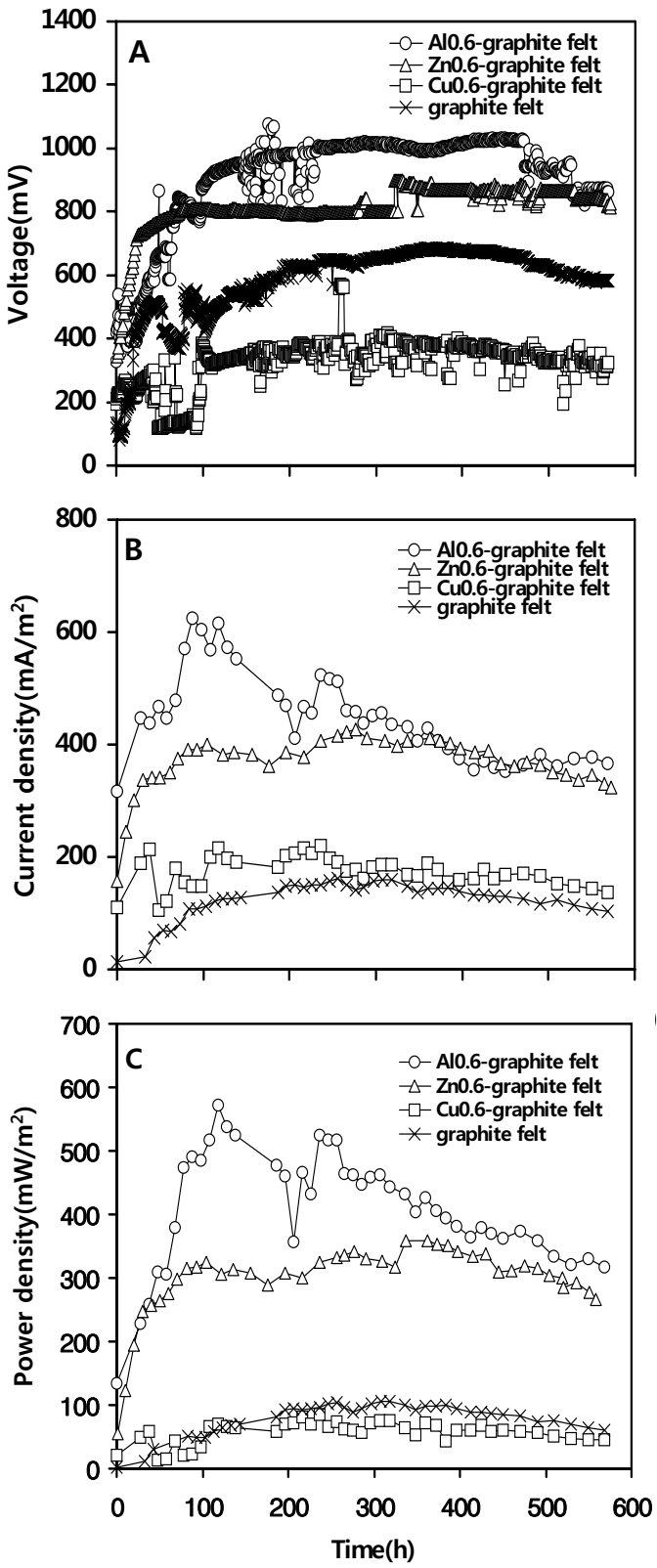

Fig. 5. Effect of metal-graphite electrodes on the performance

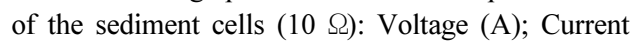
density (B); Power density (C). 
Table 6. Maximum power densities for each electrode

\begin{tabular}{cccc}
\hline \multirow{2}{*}{ Electrode } & \multicolumn{3}{c}{ Maximum power density $\left(\mathrm{mW} / \mathrm{m}^{2}\right)$} \\
\cline { 2 - 4 } & Metal 0.2 g & Metal 0.4 g & Metal 0.6 g \\
\hline \hline \multirow{2}{*}{ Al-C } & 194 & 493 & 571 \\
Zn-C & 202 & 293 & 358 \\
Cu-C & 102 & 186 & 81 \\
\hline Graphite felt & \multicolumn{3}{|c}{105} \\
\hline
\end{tabular}

\section{4. 탄소전극과 복합전극의 전기저항 고찰}

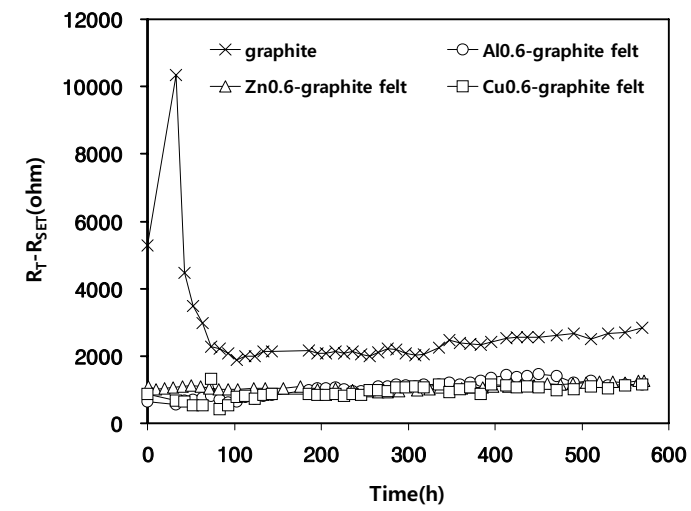

Fig. 6. Total resistance changes in sediment cells with metalgraphite felt electrodes.

Fig. 6은 V-I 실험 데이터로부터 전체저항을 도출 한 다음 외부 고정저항을 제외하여 내부저항을 도출 한 것이다. 금속-탄소 복합전극을 사용한 경우 전체저 항은 초기부터 실험을 마칠 때까지 $1000 \sim 1200 \Omega$ 을 유지한 반면 탄소전극만을 사용한 경우 초기 50 시간 에 내부저항이 매우 높았으며(실험 초기 미생물이 환 경에 적응하며 전극에 얇은 막으로 부착되는 과도기 로 생각됨) 100 여 시간 후에는 2000 3000 $\Omega$ 정도로 안 정화되었다. 즉, $\mathrm{SEM}$ 사진(Fig. 9)에서 확인되듯이 전기 화학적 활성미생물(Electrochemically Active Bacteria: $\mathrm{EAB})$ 이 전극에 생물막을 안정적으로 생성시키는 것 으로 판단된다.

\section{5. 단위금속 면적당 전류밀도}

Fig. 7은 Zn-graphite felt 전극의 금속 면적당 전류 밀도를 도출한 것이다. Graphite felt에 각각 $0.2,0.4$,
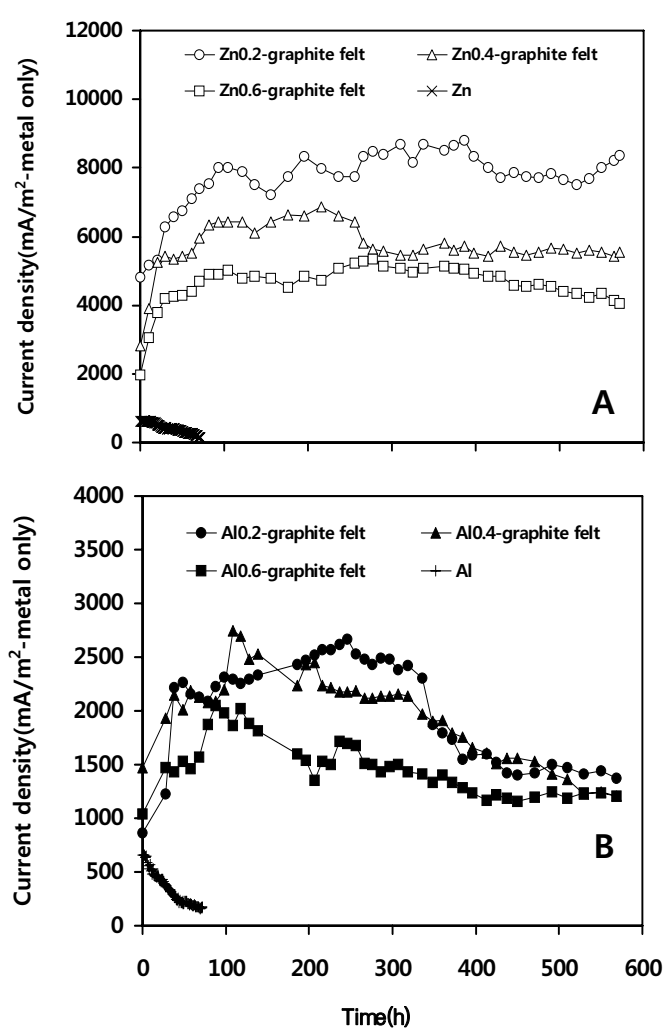

Fig. 7. Current densities per metal surface area for Zngraphite felt electrode (A) and Al-graphite felt electrode (B) cells.

$0.6 \mathrm{~g}$ 의 아연을 집적한 복합전극에서는 금속의 면적 이 작을수록 높은 전류밀도를 보였고, 알루미늄을 집 적한 복합전극에서도 같은 결과가 나타났다. 즉, 복합 전극 제조과정에서 금속의 무게에 비례하여 면적이 늘어난다는 가정 하에 전류의 배가를 기대한 것과 다 른 결과를 보였다. 이것은 금속의 면적이 커지면 금속 의 산화반응이 빠르게 일어나지만 동시에 금속의 부 식으로 인한 산화막 형성도 빠르게 진행되어 금속의 단위 면적당 전류밀도를 낮추는 것으로 판단된다. 금 속으로 인한 화학반응은 2종류로 나타나는데 첫째는 용액 중으로 이온화 경향이 강한 금속분자의 산화이 탈 즉, $\mathrm{M}^{\mathrm{n}+}$ 이온화와 수분 등 산화제에 의한 금속표면 의 부식(산화피막 형성)이다. 본 퇴적토 산화전극부에 서는 부식반응을 촉진하는 산화성 $\mathrm{H}_{2} 0$, 용존 $\mathrm{O}_{2}$ 가 존 
재하며 더욱이 해수에 폭넓게 존재하는 $\mathrm{Cl}^{-}, \mathrm{HS}^{-}$와 같 은 산화성이 강한 유- 무기물질이 공존하여 금속표면 이 증가할수록 다발적인 국소부식반응이 빠르게 진행 될 수 있다고 사료된다.

\section{6. 퇴적토의 $\mathrm{pH}$ 및 $\mathrm{COD}$ 변화}

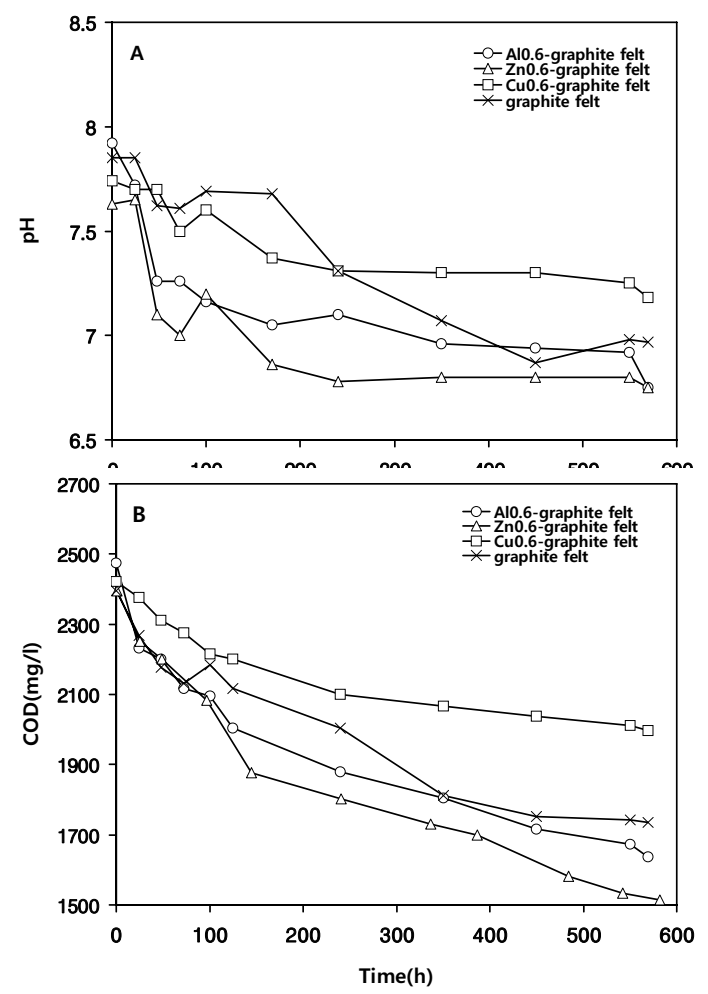

Fig. 8. Trend of $\mathrm{pH}(\mathrm{A}), \mathrm{COD}(\mathrm{B})$ changes in sediment cells using metal-graphite felt electrodes.

복합전극의 퇴적토전지 $\mathrm{pH}$ 및 $\mathrm{COD}$ 변화를 Fig. 8 에 나타내었다. 초기 산화전극 주변 퇴적물의 $\mathrm{pH}$ 는 7.7 7.9로 측정되었으며 600 시간이 지난 후 최종 $\mathrm{pH}$ 는 평균 7 로 감소하였다. 최대 $\mathrm{pH}$ 감소는 $\mathrm{Al}(0.6 \mathrm{~g})-$ graphite felt전극에서 $-1.17(7.92 \rightarrow 6.75)$ 이었다. $\mathrm{pH}$ 감소의 원인은 전극 주변의 퇴적토 유기물이 복잡한 화학반응에 의해 분해되는 과정에서 산성 물질이 생 성된 것으로 보인다. $\mathrm{pH}$ 감소가 퇴적토 내 유기물의 분해를 상징한다면 그 직접적 영향은 $\mathrm{COD}$ 감소로 나 타날 것이다. $\mathrm{COD}$ 의 변화량은 전극별로 감소율의 편
차가 컸는데 예를 들면, $\mathrm{Zn}(0.6 \mathrm{~g})$-graphite felt전극의 경우 $36.7 \%$ 의 제거율을 보였으며 $\mathrm{Cu}(0.6 \mathrm{~g})$ - graphite felt전극의 경우 $17.5 \%$ 의 최저 COD제거율을 나타내 었다. 반면 graphite felt전극의 경우 $27.5 \%$ 의 상당히 높은 $\mathrm{COD}$ 제거율을 보였는데 이는 퇴적토 내 $\mathrm{EAB}$ 에 의한 생화학적 유기물분해와 상관된다. 결론적으로 복합전극을 사용하여 발전량을 크게 할 경우 $\mathrm{COD}$ 와 같은 오염지표를 동시에 비례하여 낮출 수 있는 효과 가 있음을 알 수 있었다(Table 7).

Table 7. COD reduction during cell operation

\begin{tabular}{cccc}
\hline Electrode & $\mathrm{COD}_{0}(\mathrm{mg} / \mathrm{L})$ & $\mathrm{COD}_{\mathrm{f}}(\mathrm{mg} / \mathrm{L})$ & Reduction $(\%)$ \\
\hline \hline Al-C & 2473 & 1636 & 33.8 \\
$\mathrm{Zn}-\mathrm{C}$ & 2394 & 1515 & 36.7 \\
$\mathrm{Cu}-\mathrm{C}$ & 2422 & 1998 & 17.5 \\
Graphite felt & 2396 & 1735 & 27.5 \\
\hline
\end{tabular}

\section{7. 전극에 생성된 생물막 관찰}

Fig. 9는 탄소 및 복합전극 단면의 SEM 사진이다.

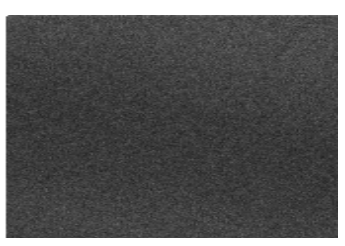

(A)

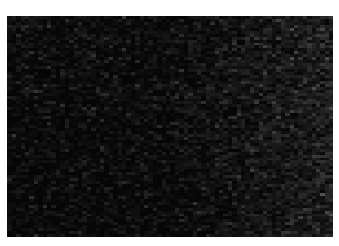

(B)
Fig. 9. SEM image of an electrode cross section: (A), graphite felt electrode; (B), $\operatorname{metal}(\mathrm{Zn}, 0.6 \mathrm{~g})$ graphite felt electrode.

(A)의 매끈한 자연 graphite felt 단면과 달리 운전 후 복합전극 (B)표면에는 미생물 형태가 국소적으로 발견되었고, 이 사실로 미루어 미량의 금속 사용은 전 극 표면에 생물막 형성을 방해하지 않음을 확인할 수 있었다.

\section{5. 결 론}

본 연구는 퇴적토전지에서 여러 전극에 따른 전기 발생특성을 고찰한 것이며 결론은 다음과 같이 요약 된다. 
1) 삽교호 수저 퇴적토는 수심이 깊은 지역일수록 유기물 함량이 높으며, 퇴적토전지의 전기발생과 연 관성이 있다고 보여 진다. 2) 탄소전극과 복합전극을 사용한 퇴적토전지는 약 100 시간 후 안정적인 전위차 를 보였고 600 시간 동안 지속적인 전기발전을 유지하 였다. 한편 금속전극은 운전 시작과 동시에 높은 전압 과 전류를 발생하지만 전극의 급격한 부식반응으로 인한 전극주변 산화막에 의해 지속적인 전기발전이 불가능하였다. 3) 각 퇴적토전지의 최대전력밀도는 탄소전극을 사용했을 시 $105 \mathrm{~mW} / \mathrm{m}^{2}$, 금속전극의 경 우 Zn전극을 사용했을 시 $635 \mathrm{~mW} / \mathrm{m}^{2}$, 복합전극의 경우 $\mathrm{Al}(0.6 \mathrm{~g})$-graphite felt전극을 사용했을 시 $571 \mathrm{~mW} / \mathrm{m}^{2}$ 을 나타냈다. 4) 단위 금속면적당 전류밀도를 비교해보 면 금속 무게가 적을수록 전류밀도가 높아졌고, 면적 이 증가할수록 그 수치가 낮아졌는데 복합적인 금속 표면에서의 부식반응속도가 매우 높음을 반증하였다. 5 ) 퇴적토의 $\mathrm{pH}, \mathrm{COD}$ 는 시간이 경과할수록 감소하는 특징을 보였으며, 600 시간 동안 운전한 경우 탄소전 극은 $27.5 \%, \mathrm{Zn}(0.6 \mathrm{~g})$-graphite felt전극은 $33.8 \%$ 의 $\mathrm{COD}$ 감소를 나타내었다.

\section{참 고 문 헌}

강병종, 2008 , 천연해수환경 중 강판에 클래딩한 스테인 리스강 박판의 부식 방식 특성, 석사학위논문, 한국 해양대학교.

노정빈, 황용우, 배재호, 문진영, 2006, 미생물연료전지 를 이용한 유기산으로부터 전기생산 특성, 상하수도 학회지, 20(2), 225-234.

배재근, 오종민 편저, 2002, 토양오염 측정분석, 신광문 화사, 59 .

Choo, Y. F., Lee, J. Y., Chang, I. S., Kim, B. H., 2006, Bacterial communities in microbial fuel cells enriched with high concentrations of glucose and glutamate, Microbiol. Biotechnol., 16(9), 1481-1484.
Du, Z., Li, H., Gu T., 2007, A state of the art review on microbial fuel cells: A promising technology for wastewater treatment and bioenergy, Biotechnol. Adv., 25, 464-482.

Jones, D. A., 1996, Principles and prevention of corrosion, 2nd ed., Prentice Hall, N.Y., 55-64.

Liu, H., Ramnarayanan, R., Logan, B. E., 2004, Production of electricity during wastewater treatment using a single chamber microbial fuel cell, Environ. Sci. Technol., 38(7), 2281-2285.

Liu, H., Logan, B. E., 2004, Electricity generation using an air-cathode single chamber microbial fuel cell in the presence and absence of a proton exchange membrane, Environ. Sci. Technol., 38, 4040-4046.

Logan, B. E., Regan, J. M., 2006, Electricity-producing bacterial communities in microbial fuel cells, Trend in Microbiology, 14(12), 512-518.

Lovley, D. R., 1991, Dissimilatory Fe(III) and Mn(IV) reduction, Microbiol. Rev., 55, 259-287.

Lovley, D. R., 2006, Microbial energizers: Fuel cell that keep on going, Microbe., 1(7), 323-329.

Oh, S. J., Min, B. K., Logan, B. E., 2004, Cathode performance as a factor in electricity generation in microbial fuel cells, Environ. Sci. Technol., 38, 4900-4904.

Robin, M., Allen, H., Peter, B., 1993, Microbial fuel cells-Electricity production from carbohydrates, Biochem. Biotechnol., 39, 27-40.

Schroder, U., Niessen, J., Scholz, F., 2003, A generation of microbial fuel cells with current outputs boosted by more than one order of magnitude, Ang. Chem., 115(25), 2986-2989.

Tender, L. M., Reimers, C. E., Stecher, H. A., Holmes, D. E., Bond, D. R., Lowy, D. L., Pilobello, K., Fertig, S. J., Lovley, D. R., 2002, Harnessing microbial power generation on the seafloor, Nat. Biotechnol., 20, 821-825. 